\title{
ARTYKUEY
}

Zdeněk Uhlír

Praga

\section{Łacińskie i czeskie kazania w XIV i XV wieku - przekład, adaptacja, mutacja}

Istnieją trzy różne spojrzenia na piśmiennictwo czeskie doby średniowiecza i początku nowożytności: ludowe (może raczej narodowe?), dla którego liczą się tylko teksty napisane po czesku; spojrzenie ludzi wykształconych (może nazwać je raczej intelektualnym?), które do pism po czesku dorzuca także łacińskie; oraz spojrzenie patriotyczne (może raczej uniwersalistyczne?), dostrzegające oprócz czeskich i łacińskich także pisma w języku niemieckim. Podczas gdy dwa pierwsze wyrażają podejście kulturowo-etniczne, czyli hołdują przekonaniu, że istnieje tzw. naród kulturowy, to trzecie jest wyrazicielem przeciwnego poglądu: że istnieje coś takiego jak naród polityczny. W badaniach dziewiętnastoi dwudziestowiecznych przeważały - wręcz dominowały - dwa pierwsze podejścia. Żadnego z nich nie podzielam, ponieważ oba stoją w sprzeczności zarówno ze średniowiecznym pojęciem narodu politycznego, jak $\mathrm{z}$ nowoczesną koncepcją narodu obywatelskiego, civitas humana. Jestem za to zwolennikiem trzeciego ujęcia, uznającego naród polityczny, ponieważ odpowiada ono swobodom i wolności współdziałania ludzi a także wolności konkurencji.

Artykuł ten powstał jako referat na konferencję „Textgestaltung als Abbild der Transformationsprozesse vom XV bis XVII Jahrhundert - Umbrüche innerhalb der Schriftlichkeit in profanen und sakralen Übersetzungstexten des Deutschen, Tschechischen und Polnischen", która odbyła się 26 września 2012 w Zgorzelcu. 
Natychmiast pojawiają się jednak trudności i niejasności terminologiczne. Po pierwsze: o ile język czeski ma na określenie wszystkich tych trzech możliwości jeden wspólny przymiotnik český, o tyle w niemieckim jest to raczej kłopotliwe, jeśli nie wręcz niemożliwe - w języku tym istnieje bowiem rozróżnienie między tschechisch a böhmisch. Dawniej również angielski posługiwał się na wzór niemieckiego dwoma różnymi określeniami: Czech i Bohemian, ale ostatnio przejął raczej terminologię czeską i używa tylko przymiotnika Czech. Podobnie wygląda to we francuskim, polskim i włoskim, które mają odpowiednio po jednym przymiotniku: tchèque, czeski oraz cecco. Słowacki i węgierski mają swoje (także pojedyncze) przymiotniki: český i cseh. Powstaje pytanie, czy istnienie w niemieckim dwóch przymiotników określających czeskość ma jakąś głębszą podstawę, czy stanowi jedynie efekt nowożytnego nacjonalizmu, który z czasem przeminie ${ }^{1}$. Reasumując: przymiotnik „czeski” odnoszę do piśmiennictwa powstałego w granicach średniowiecznych ziem czeskich, czyli Czech, Moraw, Śląska i Łużyc - niezależnie od tego, czy chodzi o teksty po czesku, niemiecku, czy po łacinie.

Dobrym przykładem, który można w tym kontekście przywołać, jest kronika tzw. Dalimila ${ }^{2}$. Napisana wierszem, jest szeroko znana jako pierwsza kronika w języku czeskim. Mniej znany jest fakt, że została przetłumaczona również na niemiecki i na łacinę. Słowo „przetłumaczona" nie jest może w tym przypadku najwłaściwsze, gdyż nie oddaje właściwego stanu rzeczy. Wszystkie wersje - czeska (powstała w latach 1310-1314), łacińska (1331-1333) oraz najpóźniejsza, niemiecka (1342-1346) są raczej częściami tego samego tekstu pierwotnego, niż tekstem podstawowym i jego dwoma przekładami. A zatem czeska literatura - ba, czeskie piśmiennictwo w ogóle - były trójjęzyczne, czeskołacińsko-niemieckie. Nie oznacza to oczywiście, że wszyscy mieszkańcy czy nawet tylko ludzie wykształceni byli trójjęzyczni, tym niemniej kronika zapisana w tych trzech językach pozwala wysnuć wniosek, że taka trójjęzyczność nie była czymś wyjątkowym. Tymczasem piśmiennictwo historyczne, zarówno czesko-, jak niemieckojęzyczne, z trudem przyjmuje

\footnotetext{
${ }^{1}$ Kwestia ta jest być może bardziej złożona. Język czeski używa nazwy Čechy, niemiecki - Böhmen, stąd české země, albo die böhmischen Länder, poza tym także Česko albo Tschechien. Podobnie w angielskim używa się z jednej strony Bohemia, a z drugiej Czech Lands (historycznie) lub Czechlands (zamiast Czech Republic). Nie zajmuję się w ogóle pejoratywnym określeniem Tschechei.

${ }^{2}$ Zob. Z. Uhliřr, Nově objevený zlomek latinského prekladu Kroniky tak řečeného Dalimila, „Knihovna: Knihovnická revue”, 16:2005, z. 2, s. 137-169.
} 
ten fakt do wiadomości, choć może powoli zaczyna się to zmieniać, zważywszy na drobne przykłady, zapoczątkowane przez Vaclava Boka ${ }^{3}$.

Kaznodziejstwo jest jednak specyficzną dziedziną, która w przeciwieństwie do literatury, będącej wyłącznie piśmiennictwem, oscyluje pomiędzy językiem mówionym a pisanym, między ustną wypowiedzią a tekstem, między retoryką a literaturą. Istnieje pomiędzy dwoma biegunami: między powstaniem (installation) a wykonaniem (performance), tzn. między napisaniem a wypowiedzeniem. To, co zostało tylko wypowiedziane, wygłoszone, ginęło następnie bez śladu; w różnej postaci przetrwały tylko pisemne wersje ${ }^{4}$. Większość homilii zachowała się w zbiorach kazań, a tylko niektóre występowały w średniowiecznych rękopisach jako samodzielne utwory, niezależne od większych całości. Z rozległej spuścizny różnorodnych kazań postaramy się stworzyć ich najprostszy obraz.

Można wyróżnić kilka form, w jakich średniowieczne homilie przetrwały do naszych czasów. Oto najważniejsze z nich: (1.) kazanie w postaci przygotowanego materiału albo autorskiej koncepcji; (2.) kazanie jako pisemny szkic albo tekst spisany przez słuchającego; (3.) kazanie jako pisemna redakcja własnej, wygłoszonej już homilii; (4.) kazanie jako redaktorskie opracowanie tekstu innego autora; (5.) kazanie przykładowe albo wzorcowe - pisemna wersja homilii, przygotowana na potrzeby mniej doświadczonych kaznodziejów (czyli tekst czysto literacki, nigdy nie wygłoszony, nie zawierający żadnych odniesień do języka mówionego).

Reasumując: kiedy mówimy o analizie jakiegoś kazania lub zajmujemy się wybranym kaznodzieją, to musimy pamiętać, że wszelkie źródła, jakimi się posługujemy, są zaledwie niejasnym śladem tylko jednej stro-

${ }^{3}$ Zob. V. Bok, Wolfenbüttelský fragment německého překladu Pulkavovy kroniky, ,Listy filologické", 113:1990, z. 1, s. 24-31; tenże, Zu literarischen Kontakten zwischen Österreich und Südböhmen bis zum Beginn des 15. Jahrhunderts, „Germanoslavica”, 4:1997, z. 1, s. 5-14; tenże, Eine tschechische Prosabearbeitung des Troja-Stoffes von 1557 und ihre lateinischen und deutschen Vorstufen, „Relationes Budvicenses: Miscellanea philologiae classicae", 2:2001, s. 15-28; tenże, Einige Beobachtungen zur lateinischen Legende über Agnes von Prag zu ihren mittelalterlichen deutschen und tschechischen Übertragungen, [w:] Selecta Bohemico-Germanica, Münster 2003, s. 163-178; tenże, Imperator-Kiser-Cyesars: Die dreisprachigen Vakabulare für Ladislaus Postumus und Maximilian I, „Germanoslavica", 16:2005, z. 1, s. 97; tenże, Svatováclavská legenda Men lest van Wenselaus $z$ düsseldorfského rukopisu Zlaté legendy, [w:] Querite primum regnum Dei: Sborník př́spěvků k poctě Jany Nechutové, Brno 2006, s. 323-331.

${ }^{4}$ Zob. Z. Uhlî́r, Středověké kazatelské sbírky a jejich místo v procesu kázání, [w:] Przestrzeń religijna Europy Środkowo-Wschodniej w średniowieczu - Religious Space of EastCentral Europe in the Middle Ages - Materiaty Konferencji Międzynarodowej Komisji Historii Porównawczej Chrześcijaństwa (CIHEC), Lublin - Lwów 6-10 września 2007, pod red. K. Brachy i P. Krasa, Warszawa 2010, s. 211-220. 
ny działalności kaznodziejskiej, mianowicie świadczą jedynie o kazaniach napisanych, a nie o wygłoszonych.

Ta jednostronność zachowanych źródeł homiletycznych znacząco wpływa na badanie trójjęzyczności średniowiecznych tekstów na ziemiach czeskich. Większość czternasto- i piątnastowiecznych rękopisów napisana została po łacinie, a tylko nieliczne po czesku lub po niemiecku. Nie oznacza to jednak, że zachowane w nich kazania w rzeczywistości wygłaszano po łacinie; było właśnie odwrotnie. Głoszenie kazań po łacinie było czymś absolutnie wyjątkowym - choć większość zachowanych przykładów napisana została w tym języku - i miało miejsce jedynie wówczas, gdy słuchaczami byli duchowni lub inni wyksztaceni ludzie, a więc na Uniwersytecie albo na synodach ${ }^{5}$. Wszystkie inne głoszono w językach narodowych, czyli po czesku i po niemiecku, aby były zrozumiałe dla słuchaczy. W niektórych przypadkach jesteśmy w stanie wyraźnie określić, w jakim otoczeniu językowym funkcjonował konkretny rękopis, ale większość manuskryptów nie pozwala na takie wnioski, i wobec tej większości pozostajemy bezradni. Poza tym zbyt mało wiemy na temat wzajemnych stosunków, odniesień i przenikania się tych trzech światów językowych oraz kręgów kulturowych, by formułować zasadne przesłanki i wyciągać jasne wnioski. Należałoby przeprowadzić dogłębne studia kodykologiczne i dyplomatyczne rękopisów zawierających kazania, aby uzyskać obszerniejszą i głębszą znajomość tych zagadnień. Wiadomo jednak - ars longa, vita brevis ${ }^{6}$.

$\mathrm{Z}$ dotychczasowych uwag na temat dziejów homilii na ziemiach czeskich w okresie rozkwitu i schyłku średniowiecza ${ }^{7}$ wynika, że wobec niedostatków źródeł i badań nie możemy na razie stawiać sobie zbyt ambitnych zadań w odniesieniu do trójjęzycznych wersji kazań oraz ich rękopiśmiennego przekazu do naszych czasów. W granicach naszych możliwości leży raczej porównanie ze sobą dwóch tekstów, wykazujących wspólne pochodzenie albo cechy różne tekstu pierwotnego ${ }^{8}$ i zbadanie dwóch, nie trzech poziomów językowych. $\mathrm{Z}$ tego względu zdecydowałem

${ }^{5}$ Por. Gerald Robert Owst, Preaching in Medieval England: An Introduction to Sermon Manuscripts of the Period c. 1350-1450, Cambridge 1926 (nowe wyd. New York 1965); tenże, Literature and Pulpit in Medieval England: A Neglected Chapter in the History of English Letters and of the English People, Cambridge 1933 (nowe wyd. Oxford 1966).

${ }^{6}$ Dobre zaplecze do studiów nad środkowoeuropejskimi rękopisami stanowi „Manuscriptorium: Building Virtual Research Environment for the Sphere of Historical Resources", zob. http://www.manuscriptorium.com

7 Zob. też Z. Uhlíŕ, Středověké kazatelství v českých zemích: nástin problematiky, „Almanach Historyczny”, 7:2005, s. 57-93, dostępny także na stronie http://digit.nkp.cz/mns/uhlir_kazatelstvi.htm [21 09 2012].

8 Zob. Z. Uhlír, Digital Codicology and Contextual Editing of Medieval Manuscripts, „Revista arhivelor - Archives Review”, 86:2009, z. 2, s. 36-54 wraz z bibliografią. 
się na porównanie řeči nedělní a sváteční Tomasza ze Štitnego ${ }^{9}$ i Quadragesimale oraz Sermones post Quadragesimam Jana Milicza z Kromieryża ${ }^{10}$ oraz Postilli Jana z Rokycan ${ }^{11}$. Tekst Štitnego napisany został po czesku, Jana Milicza po łacinie, a tekt Rokycana jest dwujęzyczny, czesko-łaciński. Mam świadomość, że ten wybór można uznać za jednostronny, ponieważ wszyscy trzej autorzy należeli do jednego nurtu religijnego. Uważam jednak, że warto wyjść od tego, co znane, z nadzieją, że dowiemy się czegoś nowego i nieznanego.

Mimo że Tomasz ze Štitnego pisał po czesku, a Jan Milicz z Kromieryża po łacinie, obaj stosowali tę samą metodę pisania kazań, polegającą na opracowywaniu starszych tekstów łacińskich. Różnica między nimi polega między innymi na tym, że u Tomasza możemy mówić o przekładzie, natomiast u Milicza o adaptacji. Chociaż więc podane teksty obu autorów wydają się od siebie różnić, to w istocie są do siebie podobne, ponieważ obaj autorzy posługują się tą samą metodą myślową i pisarską ${ }^{12}$. Tomasz ze Štitnego nad inne metody przedkłada tłumaczenie, natomiast Milicz z Kromieryża duże znaczenie przypisuje adaptacji autorytatywnych tekstów patrystycznych - oznacza to, że obaj stosują tę samą metodę tworzenia kazań, opartą na rozkładaniu i dalszym przekazywaniu istniejących tekstów ${ }^{13}$, tak że obaj mieszczą się w szerszych ramach średniowiecznego piśmiennictwa środkowoeuropejskiego. Jeśli w dodatku zachowują podstawowe zasady tekstu, z którego czerpią, to

${ }^{9}$ Zob. Z. Uhlír̆, $O$ „Řečech nedělních a svátečních“ Tomáše ze Štítného: Problém české a latinské transmise kazatelských textù, „Z badań nad książką i księgozbiorami historycznymi”, 4:2010, s. 81-90 wraz z bibliografią.

${ }^{10}$ Zob. Z. Uhlíŕ, Milič z Kroměř̌že a kazatelský styl jeho homilii, [w:] Manu propria... Sbornik př́spěvkù k životnímu jubileu Aleny Richterové, Z. Adamaitis, T. Paličková, (eds.), Praha 2012, s. 25-34; tenże, „Quadragesimale“ Miliče z Kroměř̌že (w druku); tenże, Milič z Kroměř́že a Tomáš ze Štítného: podhoubí reformního a husitského kazatelství (w przygotowaniu).

11 Zob. František Šimek, Postilla Jana Rokycany, t. I-II, Praha 1928-1929; tenże, Učení M. Jana Rokycany, Praha 1938.

${ }_{12}$ Por. Tomáš ze Štítného: Sborník vyšehradský, F. Ryšánek, J. Daòhelka (eds.), t. I-II, Praha 1960-1969; Pavlína Rychterová, Die Offenbarungen der heiligen Birgitta von Schweden: Eine Untersuchung zur alttschechischen Ubersetzung des Thomas von Stitné (um 1330 - um 1409), Köln 2004; Vidění svaté Brigity Švédské v překladu Tomáše ze Štítného, P. Rychterová (ed.), Praha 2009; Tomáš ze Stitného: Řeči nedělní a sváteční, J. Straka (ed.), Praha 1929. Por. też Pavlína Rychterová, František Šmahel, Die Offenbarungen der heiligen Birgitta von Schweden: eine Untersuchung zur alttschechischen Übersetzung des Thomas von Štítné (um 1330 - um 1409), „Dějiny - teorie - kritika”, 4:2007, z. 1, s. 124-127; Venda Svobodová, Ediční experiment, „Protimluv”, 8:2009, z. 4, s. 28-29; Vendula Svobodová, Rekonstrukce versus objektivita, „Česká literatura”, 59:2011, z. 1, s. 91-93.

${ }^{13}$ Por. Adolf Spamer, Über die Zersetzung und Vererbung in den deutschen Mystikertexten, Giessen 1910. 
mieszczą się nie tylko w ramach piśmiennictwa środkowo-, ale także ogólnoeuropejskiego ${ }^{14}$.

Podstawowe zasady tworzenia kazań są wprawdzie u obu autorów Tomasza ze Štitnego i Milicza z Kromieryża - takie same, ale same kazania różnią się zewnętrzną formą. Tomasz ze Štitnego jest bardziej elastyczny niż stosunkowo sztywny Milicz: swobodnie opracowuje teksty, na których się wzoruje, łącząc wolny, adaptacyjny przekład z własnymi słowami w ten sposób, by powstało wrażenie spójności i jednolitości nowego utworu. Często posługuje się elementami stylu retorycznego, a nawet oratorskiego, aby czytelnik miał nieodparte wrażenie, że to kazanie istotnie zostało wygłoszone, chociaż najpierw powstało przecież jako tekst czysto literacki ${ }^{15}$. Mieści się to w ramach europejskiego rozwoju homiletyki: wszędzie bowiem sięgano po środki, mające stworzyć wrażenie oratorstwa, złudzenie słowa mówionego (chociaż chodziło o teksty wyłącznie literackie), zarówno w pojedynczych kazaniach, jak w ich zbiorach ${ }^{16}$. Należy ponadto pamiętać, że Řeči nedělní a sváteční nie były przeznaczone do cichego czytania, lecz do odczytywania na głos, zatem uprawnione jest używanie środków właściwych stylowi retorycznemu. Możemy bowiem przyjąć, że Řeči nedělní a sváteční Tomasza ze Štitnego pełniły funkcję collatio, a więc pewnego uzupełnienia kazania (sermo) i służyły do odczytywania podczas zgromadzenia niewielkiej grupy wiernych. W tej sytuacji złudzenie użycia języka mówionego stanowiło wyraz wspólnego życia religijnego, jakie towarzyszyło procesowi postępującej laicyzacji późnośredniowiecznego Kościoła na drodze ku reformacji (w znaczeniu ecclesia semper reformanda).

${ }^{14}$ Por. John Bryant, The fluid Text: A Theory of Revision and Editing for Book and Screen, Ann Arbor, Mich. 2002; Joachim Bumke, The Fluid Text: Obvservations on the History of the Transmission and Textual Criticism of the Thirteenth-Century Courtly Epic, New York 2005. Por. John Ernest, The Floating Icon and the Fluid Text: Rereading the „Narrative of Sojourner Truth“, Durham, NC 2006; J. Bryant, Melville Unfolding: Sexuality, Politics, and the Version of Typee: A Fluid-Text Analysis, with an Edition of the Typee Manuscript, Ann Arbor, Mich. - London 2008.

15 Josef Jireček, ̌̌eči nedělní a sváteční, „Časopis českého muzea”, 35:1861, s. 171-175; Josef Straka, Štítného Řeči nedělní a sváteční, „Listy filologické”, 35:1908, s. 35-40, 130-136, 226-234, 347-359; 36:1909, s. 35-39, 117-121, 240-151, 450-462; 37:1910, s. 99-108, 229-249; tenże, K staročeské literatuře náboženské, „Listy filologické”, 51:1924, s. 28-42, 135-146; Barbora Hanzová, Autorská promluva Tomáše ze Stitného $v$ Řečech nedělních a svátečních, [w:] Varia XVIII. Zborník príspevkov z XVIII. Kolokvia mladých jazykovedcov (Prešov - Kokošovce - Sigord 3.-5.12.2008), M. Ološtiak, M. Ivanová, L. Gianitsová-Ološtiaková (eds.), Prešov 2009, s. 209-213.

16 Por. Jindřich Marek, Jakoubek ze Střbra a počátky utrakvistického kazatelství $v$ českých zemích: studie o jakoubkově postile z let 1413-1414, Praha 2011. Inaczej K. Bracha, Nauczanie kaznodziejskie w Polsce późnego średniowiecza: „Sermones dominicales et festivales" $z$ tzw. kolekcji Piotra z Mitostawia, Kielce 2007. 
Milicz z Kromieryża w swoim Quadragesimale czy w Sermones post Quadragesimam posługuje się w sposób prostszy i bardziej bezpośredni łacińskimi tekstami patrystycznymi i monastycznymi. Do minimum redukuje własny autorski tekst, tak że istotną część jego kazań (w tym przypadku homilii egzegetycznych) zajmują cytaty patrystyczne i monastyczne. Kazania Milicza z Kromieryża przypominają zatem formą późnoantyczne centony, gdzie obszerne cytaty łączą się z krótkimi komentarzami odautorskimi. Dotychczasowi badacze jego utworów nie zauważyli jednak tej cechy ${ }^{17}$. Duże znaczenie ma również fakt, że o ile Tomasz ze Štitnego wybierał cytaty patrystyczne i monastyczne samodzielnie, kierując się własnym pomysłem, o tyle Milicz z Kromieryża opierał się na istniejących wyborach, głównie na Tomaszu z Akwinu. Korzystał zwłaszcza z takich jego dzieł jak Catena aurea in Matthaeum, Catena aurea in Marcum, Catena aurea in Lucam oraz Catena aurea in Iohannem, a czasami także z Summa theologiae. Mamy tu do czynienia z interesującym paradoksem: Milicz z Kromieryża to właściwie Tomasz z Akwinu. Jest to jednak paradoks, który można zrozumieć, gdyż Milicz bliski był ruchowi devotio moderna, a ten odrzucał scholastykę, akceptując równocześnie przedscholastycznego ducha patrystycznego i monastycznego wraz z jego sposobem myślenia. Warunki te spełniała Catena aurea Tomasza z Akwinu, gdyż jako zbiór materiałów i argumentów do dyskusji przywoływała wyłącznie dawniejsze dowody.

Milicz był nie tylko związany z ruchem devotio moderna, ale towarzyszył też narodzinom czeskiego ruchu religijnego. Reformacja husycka, która była istotną częścią tzw. pierwszej reformacji, poszła śladem tamtych pierwotnych idei. Należy uświadomić sobie pewną drobną kwestię: otóż czeska pierwsza reformacja nie chciała naśladować Kościoła apostolskiego (jak angielski ruch Wyclifa), lecz dążyła do naśladownictwa Kościoła patrystycznego ${ }^{18}$. Dlatego zrozumiałe jest, co miały znaczyć słowa kázání slova božího, czyli głoszenie słowa Bożego. W żadnym ra-

17 Zob. František Loskot, Milič z Kroměřžže, otec české reformace, Praha 1911; Miloslav Kaňák, Milič z Kroměř́že, Praha 1975; por. też niem. przekład, Miloslav Kaňák, Milič aus Kremsier: Der Vater der böhmischen Reformation, Berlin 1981; Peter C. Morée, Preaching in Fourteenth-Century Bohemia: The Life and Ideas of Milicius de Chremsier (†1374) and His Significance in the Historiography of Bohemia, Heršpice 1999, por. recenzję Z. Uhlíra, „Miscelanea Oddělení rukopisù starých tisků”, 15:1998, s. 398-399; por. też P. Morée, The Dating of the Postils of Milicius de Chremsir, „Listy filologické”, 121:1998, z. 1-2, s. 64-83; tenże, The Role of the Preacher According to Milicius de Chremsir, [w:] The Bohemian Reformation and Religious Practice, t. 3, 1998, s. 35-48.

${ }^{18}$ Zob. Zdeněk V. David, Finding the Middle Way: The Utraquists' Liberal Challenge to Rome and Luther, Washington 2003; por. też przekład czeski tenże, Nalezení střední ce- 
zie nie oznaczały one wyłącznie posługiwania się cytatami ze Starego i Nowego Testamentu, lecz miały być naśladowaniem dawnej, tzn. właściwej interpretacji kérygmy, euangelionu - czyli Pisma Świętego. Milicz z Kromieryża pisze dość enigmatycznie, że kaznodzieje mają głosić słowo boże - ale rozumie to jako naśladowanie pism patrystycznych, a nie jako proponowanie własnych, oryginalnych interpretacji Biblii.

Tomasz ze Štitnego i Jan Milicz z Kromieryża są bardzo interesującymi osobowościami o istotnym znaczeniu dla historycznych dziejów swoich czasów. Padli jednak ofiarą przestarzałych wyobrażeń na temat ruchów religijnych Europy w dobie późnego średniowiecza i na temat ówczesnego społeczeństwa. Trzeba pokonać długą drogę, żeby zmienić to przestarzałe rozumienie. Podobnie rzecz się ma z husyckim arcybiskupem Janem z Rokycan. Dopiero ostatnio pojawiają się próby nowej oceny drogi, jaką odbył kościół czeski od husyckiego utrakwizmu, wyrażającego się w tzw. teologii kielicha, przez utrakwizm kompaktatowy, który pod wpływem soboru w Bazylei stał się etnograficzną osobliwością, aż do utrakwizmu czeskiego kościoła narodowego, wspierającego kościół nieteologiczny ${ }^{19}$. Z drugiej natomiast strony brak jakiejkolwiek nowej interpretacji i oceny stosunku Jana z Rokycan do Piotra Chelczyckiego, prekursora Braci Czeskich. Podobnie brak porównania myśli i działalności Jana z Rokycan oraz jego towarzysza i przeciwnika, Vaclava z Drachova. Nie ma też nowego porównania Jana $z$ Rokycan $z$ jego protagonistami z tzw. kościoła narodowego Jana z Pribrami oraz z Prokopem z Pilzna.

Wydaje się jednak, że Jan z Rokycan był dość praktycznym człowiekiem, tzn. z jednej strony był gotowy na kompromis, z drugiej zaś pozostawał blisko zwykłych ludzi. Jego kazania zdają się to potwierdzać. Możemy przyjąć, że stanowią one efekt połączenia dwóch etapów, tzn. powstały jako pisemne opracowanie kazań rzeczywiście wygłoszonych przez autora, ale następnie oryginalne teksty Jana z Rokycan opracowywał jeszcze jakiś redaktor. W konsekwencji tego zabiegu ich styl został do pewnego stopnia ujednolicony, jednakże pozostały w nich zwroty do słuchaczy o sarkastycznym często charakterze. Wydaje się, że zwroty traktujące słuchacza jako ograniczonego umysłowo czy leniwca kierowa-

sty: liberální výzva utrakvistio Římu a Lutherovi, Praha 2012. Por. Renáta Modráková, Z. Uhliř, Zákon a Písmo: Rukopisy české reformace 14.-16. století, Praha 2009 [przekład ang. Law and Scripture: Manuscripts of the Czech Reformation in the 14th-16th centuries, Prague 2009].

${ }_{19}$ Zob. niepublikowaną dotąd dysertację na wydziale teologii ewangelickiej, Dušan Coufal, Polemika o kalich mezi teologii a politikou 1414-1431: Př́spěvek k predpokladùm basilejské disputace o první z pražských artikulù, 2012. 
ne były wprost do żyjących zgodnie z nakazami religii wiernych, jednakże by potwierdzić ten pogląd, należałoby przeprowadzić głębsze studia nad całym zbiorem tych homilii. Szczególnie istotne byłoby porównanie kazań czeskich i łacińskich oraz zestawienie kaznodziejstwa Jana z Rokycan $\mathrm{z}$ homiliami Vaclava $\mathrm{z}$ Drachova. Niezwykle interesujący jest aspekt języka czeskiego Jana z Rokycan, zupełnie niespotykany w czeskim środowisku. Niektóre z tych kazań są bowiem pisane makaronicznie, tzn. w jednym zdaniu mieszają się fragmenty po czesku i po łacinie. Nie ma to nic wspólnego z przekładem ani z adaptacją, jeszcze mniej $\mathrm{z}$ mutacją tych tekstów. Trudno rozstrzygnąć, o czym to w istocie ma świadczyć. Skłaniam się ku przypuszczeniu, że makaroniczne części w kazaniach Jana z Rokycan miały satysfakcjonować słuchaczy, którzy sami siebie uważali za ludzi wykształconych. Możemy oczywiście kwestionować głębię tego wykształcenia, ale trzeba pamiętać, że ludzie ci stanowili elitę wiernych kościoła utrakwistów (kalikstynów), więc kaznodzieja musiał liczyć się z ich obecnością i wrażeniami. Jeśli takie założenie jest prawdziwe, to świat idei Jana z Rokycan diametralnie różni się od świata Tomasza ze Štitnego i Jana Milicza z Kromieryża.

Jak widać, wyniki przedstawionych tutaj dociekań są dość mizerne. Stanowią one jednak odbicie ogólnego stanu badań nad homiletyką zarówno w Czechach, jak w całej Europie Środkowej. Nie możemy oczekiwać lepszych rezultatów bez krytycznej edycji zachowanych homilii, gdyż pojedyncze cytaty wyjęte z kontekstu całych kazań, jakie ukazują się od czasu do czasu w różnych publikacjach naukowych, nie dają możliwości wystarczającego poznania środowiska dwu- czy nawet trójjęzycznego.

tłum. Agnieszka Gadzała

\section{Streszczenie}

\section{Łacińskie i czeskie kazania w XIV i XV wieku - przekład, adaptacja, mutacja}

Artykuł poświęcony jest kwestii języka używanego w kaznodziejstwie czeskim okresu późnego średniowiecza. Autor porównał trzy zbiory kazań: Ǩeči nedělní a sváteční autorstwa Tomasza ze Štitnego (napisane w j. czeskim) i Quadragesimale oraz Sermones post Quadragesimam Jana Milicza z Kromieryża (w j. łacińskim) oraz Postilli Jana z Rokycan (w j. czeskim i łacińskim). Stwierdził, że w wypadku dwóch pierwszych autorów wyróżnić można tę samą metodę pisarską, opartą o tłumaczenie 
$\mathrm{i} /$ lub adaptację istniejących tekstów np. patrystycznych i monastycznych. Kazania tych autorów różnią się jednak formą zewnętrzną - kazania Tomasza ze Štitnego, w formie naśladujące język mówiony, służyły do odczytywania podczas zgromadzenia grupy wiernych i stanowiły uzupełnienie kazania (collatio), natomiast teksty Jana Milicza z Kromieryża zawierały głównie cytaty, zwłaszcza z tekstów Tomasza z Akwinu, z krótkim komentarzem. Natomiast kazania Jana z Rokycan stanowią połączenie dwóch etapów pracy, były one zapisem wygłoszonych przez autora kazań, poddane później opracowaniu redakcyjnemu. Autor artykułu zwrócił uwagę na konieczność powstania krytycznych edycji zachowanych kazań, umożliwiających dogłębne poznanie środowiska twórców i odbiorców, często dwu- czy nawet trójjęzycznych.

\section{Summary}

\section{Latin and Czech Sermons in the 14th and 15th Centuries: Translation, Adaptation, Mutation}

The article deals with language issues related to preaching in Bohemia during the later Middle Ages. Z. Uhlír compares the following sermon collections: Řeči nedělní a sváteční by Tomáš Štítný ze Štítného (in Czech), the Quadragesimale and the Sermones post Quadragesimam written by Jan Milíč z Kroměřǐže (in Latin), and the Postilla of Jan Rokycana (in Czech and Latin). The first two authors used the same writing method: translation and adaptation of texts by other patristic or monastic authors. But the sermons of Tomáš ze Štítného and Jan Milíè z Kroměřiže vary in their external appearance. The former imitates the spoken language; his texts were destined for reading aloud to gatherings of the faithful, and were to accompany homilies (collatio). The writings of Jan Milíč z Kroměřǐže contain chiefly quotations, in particular from Thomas Aquinas, and short comments on them. On the other hand, the sermons of Jan Rokycana demonstrate a combination of both these procedures and are a transcript of homilies actually delivered, with editorial emendations added later.

Uhliř also points to the necessity of producing modern critical editions of medieval sermons, which would enable a deeper analysis of the milieu of their authors and audiences. Moreover, we must not forget that in numerous cases these milieus were multilingual. 